\section{Mirosław Mróz}

Nicolaus Copernicus University, Toruń mmroz@umk.pl

ORCID: 0000-0003-3111-2905

DOI: http://dx.doi.org/10.12775/BPTh.2018.015
Biblica

et

Patristica

Thoruniensia

11 (2018) 3: 315-330

ISSN (print) 1689-5150

ISSN (online) 2450-7059

\title{
"Be Strong in the Lord" (Eph 6:10). The Role of the Virtue of Fortitude in Christian Life in the Light of the Commentary on the Epistle to the Ephesians by St. Thomas Aquinas
}

\author{
"Bądźcie mocni w Panu" (Ef 6,10). Rola cnoty męstwa \\ w życiu chrześcijańskim w świetle komentarza \\ św. Tomasza z Akwinu do Listu św. Pawła do Efezjan
}

\begin{abstract}
The article offers a comprehensive theological approach to the virtue of fortitude. The text examines the significance of the influence of grace on human ability to overcome difficulties when striving after goodness relying on Thomas Aquinas's Commentary on the Epistle to the Ephesians. The grace of the Holy Spirit granted to the faithful works in human mind, relying on nature and purifying it elevates it to the supernatural level. Christians are given a full understanding of the end and a new way of acting. Christian fortitude is not so much an individual effort but the act of entering the dynamics of the mystery of Christ's power, trust (fiducia) in His power, strategy and tactics. That is why, Christians receive the armor of God (armatura Dei) from Christ so that they can withstand "the powers of this dark world" (Eph 6:11:13-17). As our struggle is not only against "flesh and blood" but also "against the rulers and against the authorities" (Eph 6:12). Putting on the armor of God takes place through the grace of the Holy Spirit, mostly in the sacrament of confirmation (sacramentum conformationis). Every Christian is endowed with the benefits of election (beneficium electionis) and predestination (beneficium praedestinationis) in the Church, that is the community of believers, and in their presence he gives the testimony of faith and love. The spiritual struggle is a fight against the traps of the devil (insidia Diaboli) and spiritual forces of evil (spiritualia nequitiae), acting in the world and among other people who are on the side of evil and sin. "Be strong in the Lord and in the power of His might" (confortamini in Domino et in potentia virtutis eius) consists in being strong and ready to defense, always standing on the side of God. Christ's fortitude is the result of His experience of the mystery of Passion, Death and Resurrection in the power of love. Christian fortitude is the fruit of joining Christ, the participation in his Mystery and in the community of the Church. Aquinas's Commentary emphasizes that the power
\end{abstract}


of the grace of the Holy Spirit is the sign of participation and conformity to Jesus Christ in the service of the Church and the Gospel.

Streszczenie. Artykuł podchodzi do zagadnienia cnoty męstwa całościowo, od strony teologicznej. W tym celu wykorzystuje Komentarz św. Tomasza z Akwinu do Listu św. Pawła do Efezjan, aby zbadać znaczenie wpływu łaski na kształtujące się pod jej wpływem ludzką zdolność pokonywania trudności w dążeniu do dobra. Łaska Ducha Świętego dana wierzącym w Chrystusa działa wewnątrz psychiki człowieka, bazuje na naturze, ale ją oczyszcza i podnosi na nowy nadprzyrodzony poziom. Chrześcijanin otrzymuje pełne zrozumienie ostatecznego celu i nowego sposobu działania. Męstwo chrześcijańskie nie jest już tyle własnym wysiłkiem, ile wejściem w dynamizm tajemnicy mocy Chrystusa, oddaniem siebie w ufności (fiducia) jego sile, jego strategii i taktyce. Dlatego chrześcijanin przyjmuje „zbroję Bożą” (armatura Dei) od Chrystusa, tak aby mógł wytrwać, mierząc się z „mocami ciemności” (Ef 6,11,13-17). Walczy bowiem nie tylko przeciw „ciału i krwi”, lecz także przeciwko „Zwierzchnościom i władzom” (Ef 6,12). Inwestytura i włożenie „zbroi Bożej” dokonuje się poprzez otrzymanie łaski Ducha Świętego, przede wszystkim w sakramencie bierzmowania (sacramentum conformationis). Chrześcijanin zostaje obdarowany dobrodziejstwami, szczególnie wyboru (beneficium electionis) i przeznaczenia (beneficium praedestinationis) w przestrzeni Kościoła, czyli wspólnoty wierzących, wobec których składa świadectwo wiary i miłości. Duchowa walka dokonuje się przeciwko zasadzkom diabła (insidia Diaboli), duchom gnuśności (spiritualia nequitiae), działającym w świecie oraz wśród innych ludzi, którzy stoją po stronie zła i grzechu. "Wzmacniać się w Panu i w potędze Jego siły" (confortamini in Domino et in potentia virtutis eius) oznacza być silnym i gotowym do obrony stając po stronie Boga. Męstwo Chrystusa wypływa z Jego przejścia przez misterium męki, śmierci i zmartwychwstania w mocy miłości. Męstwo chrześcijanina jest owocem przystąpienia do Chrystusa, włączenia się w Jego misterium, i trwania we wspólnocie Kościoła, która je autentycznie przekazuje. Komentarz Akwinaty podkreśla, że moc łaski Ducha Świętego jest znamieniem uczestnictwa i upodobnienia się do Jezusa Chrystusa w służbie Kościołowi i Ewangelii.

Keywords: Thomas Aquinas; Aquinas's Commentary on the Epistle to the Ephesians; the virtue of fortitude; the grace of the Holy Spirit; spiritual struggle; the armor of God.

Słowa kluczowe: Tomasz z Akwinu; Komentarz Akwinaty do Listu do Efezjan; cnota męstwa; łaska Ducha Świętego; walka duchowa; zbroja Boża. 


\section{The "puzzle" of Thomas' Commentary on the Epistle to the Ephesians. How the secondary theme of the disposition of fortitude becomes a leading one.}

Undoubtedly, St. Paul's Epistle to the Ephesians is not easy to interpret although the main theme, namely St. Paul's doctrine on the unity of the Church with Christ as the Head and the faithful as His members seems to be clear. ${ }^{1}$ In the Prologue to his own commentary on the Romans, Thomas Aquinas notes this main theme of the Epistle to the Ephesians. ${ }^{2}$ However, this issue can be approached from different perspectives. In this thematic context, Aquinas reveals the significance of the grace of the Holy Spirit, which as the gift of God strengthens "the pillars of the Church" (columnas Ecclesiae), namely the faithful of the Church at Ephesus (fideles Ecclesaiae Ephesiorum). In his commentaries on Paul's epistles, Aquinas always begins with the so-called divisio maior (major division), in which he indicates the main themes of particular parts

1 There are many commentaries and studies concerning the Epistle to the Ephesians, but particular attention should be given to: Ambrosiaster, Commentaria in duodecim Epistolas Beati Pauli, 47-536; Super Epistolam ad Ephesios, 393-426; CSEL LXXXI: Ambrosiastri qui dicitur Commentarius in Epistolas Paulinas, 69-126; Joannes Chrisostomus, In Epistolam ad Ephesios Commentarius, 9-176; Oeuvres complètes de Saint Jean Chrysostome, 168-447; Anselmus Cantuariensis, Divi Anselmi Cantuariensia Archiepiscopi in omnes sanctissimi Pauli Apostoli epistolas enarrationes, 298-334; Erasmus Roterodamus, Adnotationes in Novum Testamentum, 549-658; T. K. Abbott, A Critical and Exegetical Commentary on the Epistle to the Ephesians and to the Colossians; J. Bajda, Rozmyślanie nad Listem do Efezjan, 67-76; M. Barth, Ephesians; R. Schnackenburg, Der Brief an die Epheser; J. Gnilka, Der Epheserbrief; A. Kinnear, Życie w Chrystusie. List do Efezjan, (org. Sit walk stand. What shall this man do?); H. Langkammer, List do Efezjan, in: Wstęp do Nowego Testamentu, 374-381; idem, Problemy literackie Listu do Efezjan, jego aspekty teologiczne i jego eklezjologia, 93-102; A. Jankowski, List do Efezjan (Pismo Święte Starego i Nowego Testamentu. W przekładzie z języków oryginalnych), 1439-1445; S. Mędala, Tajemnica Bożej ekonomii. List do Efezjan, 448-485; R. Penna, Lettera agli Efesini. Introduzione, versione, commento; J. Pytel, List do Efezjan, 169-170; R. Sikora, Kościół jako ciało Chrystusa w Kol i Ef, 29-138; E. Staniek, Bogactwo natchnionych ksiag. List do Efezjan. Jedność w Chrystusie, 30-36; idem, Żyjemy w świecie pogan; A. Suski, Il salmo di lode nella lettera agli Efesisni. Tentativo do ricostruzione ed aspetti teologici.

2 Cf. S. Thomae Aquinatis, Super Epistolas S. Pauli lectura, vol. 2: Super Epistolam ad Ephesios lectura, 1-87; Tomasz z Akwinu, Wykład Listu do Efezjan (Super Epistolam B. Pauli ad Ephesios lectura); St. Thomas Aquinas, Commentary on Saint Paul's Epistle to the Ephesians. 
of a given epistle. He follows this pattern in his Commentary on the Epistle to the Ephesians distinguishing four main parts of the epistle: firstly, the salutation in which he reveals his great attachment to the faithful in Ephesus although St. Paul was not the founder of this Church (cf. Eph 1:1-2); secondly, the strengthening of the Ephesians in their good dispositions (cf. Eph 1:3-3, 21); thirdly, the encouragement for the faithful of the Church to attain even more lofty goods (Eph 4:1-6, 9); and finally, the strengthening in the Lord and His mighty power to receive the armor of God and be ready for spiritual battle (Eph 6:10-6, 24).

It appears that according to St. Thomas none of the parts or presented themes of the Epistle to the Ephesians indicate the virtue of fortitude suggested by the topic of the paper. However, the in-depth interpretation of Thomas' commentary and return to the first sentence of the Prologue confirms the chosen perspective. "As Ovid wisely remarked: 'No less energy is spent in retaining possessions than in acquiring them." " (Sicut dicit sapiens: «non minor est virtus quam quearrere porta tuei») and this diction indicates a line of thought of the whole Epistle to the Ephesians. The Ephesians have been led to faith in Christ and have received the grace of the Holy Spirit but they required strengthening in faith (confirmatio in fide). Although St. Paul is not the founder of the Church in Ephesus he strengthens the faith of the Christians belonging to this community. They are the pillars of the Church and should remain as such. The word conformatio used by Thomas with such a great intensity and mentioned in the Prologue seven times seems to be of paramount significance. The expressions, such as confirmatio columnas; confirmato in fide; confirmato fratres tuos; artefix confirmat aedeficium, ne cadet [to strengthen its pillars (the pillars of the Church at Ephesus); to strengthen the brothers (the faithful of the Church) to strengthen in their faith as the workman will buttress a building against a fall] appear to confirm the theme of strengthening the disposition of fortitude. Thomas also adds episcopus confirmat puerum ad rabor contra pusillanimitatem [The bishop confirms a boy to fortify him against becoming spiritless]. He also refers to the biblical text from Psalm 89:21: «inveni David servum meum, oleo sancto meo unxi eum; manus enim mea auxiliabitur ei, et brachium meum confortabit eum, nihil proficiet inimicus in eo, et cetera» In this context, the Psalm 89:21 says of David: "I have found David my servant: with my holy oil I have anointed him. For my hand shall help him: and my arm shall strengthen him."

The word cofirmatio (confirmation) clearly refers to the virtue of fortitude. ${ }^{3}$ The bishop anoints the confirmed by using oil of Chrism so that the

3 Cf. S. Th., III, q. 72, a. 1c: "And thence it is that besides the movement of generation whereby man receives life of the body, there is the movement of growth, whereby man is 
confirmed could bravely confess Christ and defend Him and the Church. If the Church is the Head and the members, the confirmed receives additional strength, the power of the Holy Spirit so that Christ could reign in his everyday life, which signifies a real and external rejection of everything that could confuse the confirmed in the world. If the main theme of the Epistle to the Ephesians is to maintain the unity of the Church, the anointing of the confirmed presented in this part reveals clearly a new strength given to the confirmed, who already reborn in baptism, is strengthened in a new way (renewed ad intra to be a witness ad extra). In a new manner, anointing reveals a perfected bond with the Church to be a strong and real witness of Christ in order to proclaim and defend the faith by word and deed. The anointing of David was a sign of being chosen and loved by God and set clearly determined tasks for him. The anointed=confirmed Christian is a man endowed with the gift of being chosen and the realization of the greatness of the benefaction of being the son of God, "the son of glory" entails certain tasks, which are part of the divine salvation plan. ${ }^{4}$ In order to fulfill these tasks God gives the chosen one his power and his Spirit.

brought to the perfect age. So therefore does man receive spiritual life in Baptism, which is a spiritual regeneration: while in Confirmation man arrives at the perfect age, as it were, of the spiritual life. Hence Pope Melchiades says: "The Holy Ghost, who comes down on the waters of Baptism bearing salvation in His flight, bestows at the font, the fullness of innocence; but in Confirmation He confers an increase of grace. In Baptism we are born again unto life; after Baptism we are strengthened." (In confirmatione autem homo accipit quasi quandam aetatem perfectam spiritualis vitae. Unde Melchiades Papa dicit, spiritus sanctus, qui super aquas Baptismi salutifero descendit lapsu, in fonte plenitudinem tribuit ad innocentiam, in confirmatione augmentum praestat ad gratiam. In Baptismo regeneramur ad vitam, post Baptismum roboramur).

4 The Prologue to the Epistle clearly indicates that the virtue of fortitude has a Christological and ecclesial profile. Christians should not be afraid of the difficulties of this world because they are protected by the power of grace, the help of the community of the Church and, above all, strengthened by the intercessory prayer. This last question is discussed by Thomas in cap. 6, lect. 5, n. 368-377, in the context of his reflections on seven conditions of prayer (septem conditiones orationis). When Aquinas states that prayer should be charitable, he has in mind the intercession for all other saints (Christians who similarly to St. Paul suffer persecution and oppression (cf. cap. 3, lect. 4, n. 164-165). This prayer is a result of the power of the special anointment in the sacrament of confirmation. The intercessory prayer for the persecuted makes all Christians participants of persecution and teaches how to be steadfast in faith. For Thomas, persecution, oppression and suffering are the special "office" (speciale officium) held on behalf of all and with a salvific profit for many. Divine assistance granted through the intercession of the Church is necessary for Christians so that they are not discouraged and abandon their service as in their flesh they are completing "what is lacking in Christ's afflictions" (1 Col 1:24a). Christians cannot find this sense through hu- 


\section{Be strong in the grace in the image of Christ}

Aquinas observes that St. Paul in his Epistle to the Ephesians writes about "the holy", "exercising virtues in relation to habits", and "true knowledge in relation to faith" (ego Paulus scribo sanctis exercitio virtutum quo ad mores; fidelibus, rectitudine cognitionis quo ad fidem) ("I, Paul, write about morals to those who are holy through the exercise of virtues; and about faith to those who believe with true knowledge") (cap. 1, lect. 1, n 4).

The gift of grace and peace was received by the Ephesians from Christ Himself and it is explained that "grace" (gratia vobis) "is offered by someone in power" (a potente datur) (cap. 1, lect. 1, n. 40), "for justification from sin" (gratia iustificationis a culpa) and "peace" (pax) which contributes to "calmness of mind" (tranquilitas mentis), "for the reconciliation to God, in regard to the freedom from punishment due to sin" (reconciliatio ad Deum, quod liberationem a debita poena pro ofensa). Those who believe in Christ are free from fear of eternal punishment (hell) because they have received baptism and live in the grace so they are not the subject of this punishment and other penalties of the present life (poenalitates paesentis vitae), such as death, pain or suffering which through imitating Christ withdraw their bitterness and burden. According to

man knowledge but through the participation in the suffering of Christ "for the sake of His Body, that is, the Church" (1 Col 1:24). The teaching about the participation in the suffering of Christ emphasized in St. Paul's Epistle to the Colossians is expressed in the Epistle to the Ephesians as a "wise service to God" on the level of the intercessory prayer. Those who have been considered worthy and anointed (confortamini) require this relational charitable prayer to strengthen their spiritual maturity received during the sacrament of confirmation. In cap. 3, lect. 4, n. 164, Thomas cites the words from 2 Cor 1:6 where St. Paul speaks of mutual consoling (consolatione). Thomas emphasizes that the prayer serves the purpose of "being consoled," but, first of all, "it is for your consolation" (pro vostra consolatione). The prayer of consolation is, in fact, a comfort for those who pray as everyone who suffers is the glory of the whole Church and Her members (especially those who pray for the afflicted) take part in it. Prayer is a call to be worthy, despite one's weaknesses and insignificance, of participating in the only and great "office" of suffering. In his commentary when discussing the prayer of Christians, Thomas underlines the creative character of the Christian virtue of fortitude, which is not a simple acceptance of blows and humiliation but entering the whole salvific power of Christ and the Church. This is the virtue of fortitude in bearing the pain even if this reality does not affect Christians directly. Praying for those who suffer (this prayer must be charitable, that is fully relational) man demonstrates his power and believes that he participates in love which is created spiritually as the Body of Christ (cf. P. Murray OP, Aquinas at Prayer. The Bible, Mysticism and Poetry, especially Prayer in practice: Aquinas on St Paul 95-122). 
Thomas, it is grace present in the virtue of fortitude that "prevents the reason from being entirely overcome by bodily pain" and "the delight of virtue overcomes spiritual sorrow, inasmuch as a man prefers the good of virtue of the life of the body and to whatever appertains thereto." ${ }^{5}$

Grace and peace are not given us alone but they should help in acting and in being the example of divine power towards the world. To be strong means to submit to the power of the Resurrected Christ.

Through Christ and by the power of the Holy Spirit God grants "the faithful", namely those who believe in Christ, his blessings. In his Commentary (cap. 1, lect. 1, n. 5) Thomas enumerates six blessings: 1. "the blessing of praising God in the certainty of future beatitude" (beneficium benedictionis futurae beatitudinis); 2. "the blessing of being chosen in the foreordained separation from those headed toward destruction" (beneficium electionis, in praeordinata separatione a massa perditionis); 3. "the blessing of predestination in the foreordained community of the good, namely, of the adopted sons" (beneficium praedestinationis in praeordinata associatione cum bonis, scilicet cum filiis adoptionis); 4. "the blessing of becoming pleasing to God through the gift of grace" (beneficium gratificationis, in colltione gratiae); 5. "the blessing redeemed, liberated from the punishment" (beneficium redemptionis, in liberatione a poena); 6. "the blessing of being pardoned by having sin blotted out" (beneficium remissionis in deletione culpae).

Thomas eliminates a very serious error which may appear in the mentality of the believer, namely that someone can think that the goodness of grace and other blessings are given as rewards for earlier deeds. If we take into consideration our virtus, the power of Christian life is given us for free not because of our deeds "otherwise grace is no more grace" (alioquin gratia iam non est gratia). No one can be proud of oneself as the whole glory belongs to God. Grace does not come from us and does not depend on our will (cf. cap. 2, lect. 3 n. 95). ${ }^{6}$

5 S. Th., II-II, q. 123, a. 8.

6 In this way, grace reveals fortitude of Christ's action. The process of endowment with grace originates from the mystery of Passion, Death and Resurrection of Christ. Without losing its power grace has always a Christological character. The Christian virtue of fortitude is nothing else but conforming to Christ (conformitas Christi). However, it is not only a moral conformity (a pure moral exemplarism) but the ontological exemplarism (cf. J.-P. Torrell, Święty Tomasz z Akwinu mistrz duchowy, 163 and 119). The fortitude of grace, most of all, shapes man as a "new creation." Thus the virtue of fortitude does not refer to the power based on our own abilities, natural skills of man, but it permeates the whole human being, his spirit and body (cf. J. Vijgen, Soul or Brain: A False Dilemma? The Thomist Perspective, 71-86). In this way, it is possible to surpass the frames of natural possibilities where the moralizing action would only 
Among the favors prepared "in advance" by God, namely according to the eternal counsel of God (Thomas refers here to predestination) our good deeds are included. This does not mean, however, that the believers are passive tools in the hands of God. Good deeds (courageous acts) have been prepared by God in such a way that we can complete them thanks to our free will. Being God's cooperators, or more precisely "God's co-workers" (adiutores Dei) (cf. 1 Cor 3: 9), means that the grace of virtues towards us would not be in vain (cf. 1 Cor. 15: 10). The progress in good acts of virtues denotes "following" (ambulatio) the ways of given grace (cf. cap. 3, lect. 2, n. 100).

The revealed power of being freed from pagan life consists in the memory of the erstwhile state: it was the state of God's wrath caused by serving idols and living the life of the body by men. Present "new life" denotes a courageous reception of "the circumcision of Christ" (Thomas emphasizes here getting rid of humiliation by Jews) performed without human hands but a spiritual one based on liberating from sinful flesh (cf. Col 2:11). "The new creation" through new life in Christ and the Spirit of God and through "liberating from sinful flesh" receives a true spiritual circumcision. Receiving the grace of the Holy Spirit we allow God to perform the "circumcision" of our inside (heart, reason, will, emotions and other powers of our soul) This is the courage of "walking" in the garment of grace (cf. cap. 3, lect. 2, n. 101-104).

include the correction of some elements of life. Man remains absolutely free in his actions (cf. S. Horvat, Neuroscientific findings in the light of Aquinas' understanding of the human being, 127-153). Christians receive here a full understanding of the ultimate end and new way of action (Cf. M. Mróz, Virtue epistemology and Aquinas's Biblical Commentary to the Corpus Paulinum, 435-456). Christ invites us not to correct ourselves or to overcome natural cognitive and operative limitations but to be renewed and transformed through the power of His fortitude (Cf. J. Pieper, Vom Sinn der Tapferkeit, 56-67). Through grace it is possible to accomplish a full conversion, that is, the death for sin and new life in the Resurrected Christ. The virtue of fortitude is not an Aristotelian effort but the fortitude of the Gospel: moralizing power but the transformation through the power of grace guaranteed in entering the mystery of Christ. Jesus Himself transforms fully a new creation relying on the incorporation into His power. Thomas shows this new status of Christians (statum novum) applying St. Paul's expression renovamini spiritu (cf. Eph 4:23). This renewal is "putting on the new man" (induite novum hominem), which is the effect of the sacrament of Baptism. As Thomas indicates in the Prologue to the Epistle to the Ephesians, the sacrament of confirmation somehow "transforms" the natural human courage into the fortitude of grace which is the strength to put on the power of Christ Himself to give testimony about Him in the presence of all the faithful of the Church (cf. also Eph 4:20-24; cap. 4, lect. 7, n. 237-246). 
In order to be in unity with Christ it is first necessary to be moved by the Holy Spirit. It is the Holy Spirit that meets us and awakens the faith. By the power of our baptism, the first sacrament of our faith, life which originates from the Father is given us in the Son, it is communicated internally and personally through the Holy Spirit in the Church.

Thus Christ empowers the member of the Church, according to the perfect power of grace which is in Christ and also in the member of the Church. He does it so that a man can use this power.

\section{To be strong in the Lord in the spiritual struggle against the enemies of Christ and the Church}

Receiving God's blessing and grace might appear difficult or even infeasible for man because of his own or introduced by others pusillanimity. It is not an easy task to avoid being intimidated by "false brothers" or Satan. Thus the virtue of fortitude consists in having the audacity of spirit (audacia), and magnanimity (magnanimitas). ${ }^{7}$ In the Prologue of the Epistle to the Ephesians, Thomas mentions obstacles the faithful may encounter in building the spiritual building and in being a pillar which is always straightforward (recta), upright (erecta) and strong (forte). In the metaphor, Thomas uses the double meaning of the Latin word rectus which denotes both a straightforward and upright man. This straightforwardness indicates, on the one hand, the vertical position of the pillar and its focus on God as the aim, thus emphasizing the significance of human purpose. On the other hand, it indicates righteousness, that is, following the right way. Similarly, erectus denotes an upright man and this vertical position signifies human dignity (dignitas) and respect (reverentia). It also emphasizes human worthiness and magnanimity. The word fotis refers to physical strength, and prowess, that is courage and valor.

By indicating these features as desirable for the fideles Ecclesiae Ephesiorum, who are the addressees of the words about pillars Aquinas reminds them of being recti, erecti and forti. This is the confirmitas (confirmation, strengthening) which St. Paul seeks for the Ephesians, in the same way as St. Thomas for his disciples, and this strengthening opposes pusillanimity and mean-spiritedness. In the Prologue, Thomas introduces the reality of the vice of pusillanimity. He reflects on it in detail in The Summa, in the treatise on the vices of fortitude (q. 133). Pusillanimity (pusillanimitas) denotes be-

7 Cf. On the meaning of fear (timor) and daring/courage (audacia) cf. S. Th., II-II, q. 123 , a. 3, on the meaning of magnanimity (magnanimitas) cf. S. Th., II-II, q. 129, a. 1-8. 
ing poor-spirited which is worse than conceit or over-ambitiousness. These two vices although contradictory from the other end of excessive power and vigour are a driving force to act and may be disciplined and their energy used in a good way. A pusillanimous man does not do anything and being attached to his self-esteem favors under the cover of false humility his imagined vainglory. Thomas is afraid that the faithful overcome by this vice may lose the most precious gift - the prize of glory (praemium gloriae). If they do not even take part in the competition, what kind of trophy should they receive? Perhaps only their faint hearts. Therefore referring to the Psalm 41:12 Aquinas asks the faithful to lift their eyes to God, look upwards at the face of God: "But you have upheld me because of my integrity, and set me in your presence forever." Using these words the faithful do not boast about their power but about the blessings and the gifts of grace which they receive from God. Thus they ask for strengthening the work which God initiated in them, calling: "Strengthen, O God, what You have done for us" (Ps 68:28). And God has done great things. We are the sons of God in his Son and the heirs of the Kingdom of Heaven. Therefore being upward (rectus) we should look up where the Lord lives. The attitude of the faithful is also important for others. If they are like erected pillars (erectus), they do not make this effort only for themselves but out of justice and charity they bear responsibility towards the community.

This is not the end of Thomas' reflection on concrete ways of strengthening the faithful. He analyses the perspectives of perceiving the spiritual building referring to the virtues of faith, hope and love. Thus faith, hope and love constitute the core of Christian life, they are the pillars of Christian life. Therefore it is not surprising that Thomas applies the characteristics of pillars (recti, electi and forti) to virtues, emphasizing that the characteristic feature of the pillar of faith is righteousness, whereas the pillar of hope is characterized by grandeur and the pillar of love by firmness. This is the model that the faithful at Ephesus should follow, namely recti per fidem, erecti per spem, fortes per charitatem (straightforward in faith, upright in hope and firm in love). The image of strength applied to each virtue is also emphasized, i.e. the presence of power=strength of each of the virtues. Also theological virtues require the exceptional power of spirit to be fully realized. Pusillanimity (pusillanimitas) is excluded here as it does not exhibit any inclinations to carry out acts comparable to the possibilities of grace. In The Summa, Aquinas additionally presents the image of a servant from Mt 25:14nn and Lk 18:12nn who after receiving talents from his master dug the hole in the ground and hid his master's money and as a result of his pusillanimous fear did not put the money to work. It was him that was punished 
for his behaviour. ${ }^{8}$ The received treasure of the grace of faith, hope and love cannot be dug in the bottom of our soul but put in the sphere of the powers of soul, reason, will and passions. It is not surprising that this particular vice has been mentioned in the context of theological virtues. Christians are characterized by the virtue $=$ virtus $=$ power of faith, virtue $=$ virtus $=$ power of hope and virtue $=$ virtus $=$ power of love in order to use all the abilities of nature and grace to achieve the ultimate aim. Unfortunately, Polish language has lost much of its coloring when talking about virtues as powers directed towards the ultimate good and directs our manner of thinking about virtues to the sphere of pure moralizing. ${ }^{9}$

Without the power of theological virtues Christianity is lifeless. Therefore St. Thomas speaks of the most fundamental question for the faithful in Christ. The discovery of this system of authentic reference is of paramount significance for eternal life. It is not sufficient to possess virtues placed at the bottom of our soul, like sanctifying grace in the sacrament of baptism, but it is important to make them alive in shaping our everyday life and in leading us to a close relation with God.

In cap. 6 lect. 3, after an inner examination and relying on grace, Thomas provides detailed instructions (preacepta) of new life. First, he indicates two main solutions: to trust in the divine assistance and to live in humility of heart. However, a new man still lives in the old world which is the world of pagans where the prince of this world rules. The world of pagans is not conducive to the novelty of grace and it is necessary to put on the "armor of God" (Eph 6:11). The believer should be able to stand against the "deceits of the devil" (adversus insidias diaboli), against "principalities and powers" (adversus principes, et potestates), against the "rulers of the world of this darkness" (adversus mundi rectores tenebrarum harum), and against the "spirits of wickedness in the high places" (adversus spiritalia nequitatae in caelestibus) (cf. Eph 6: 11-12). Thomas will state clearly who the adversary in the struggle is and that he fights with God in Christ but because of his shrewdness does not launch a frontal assault but attacks the members of Christ's Body with deceit and lies. It cannot be forgotten that the main theme of the Epistle to the Ephesians is the unity of Christ and Church. ${ }^{10}$ This truth results in devil's indirect attacks on Christ through the

8 S. Th., II-II, q. 133, a. 1c.

9 Perhaps, we should agree to use the term valor (dzielność) instead of virtue (cnota) introduced by Professor D. Gromska in her translation of The Nicomachean Ethics by Aristotle.

10 St. Augustine speaks to the baptized: "You are not only become Christians, but Christ" (Homily 21, 8; PL 38, 168). This truth is present in the mystery of the Church as the mystic Body of Christ. 
believers, through the weaknesses of people, namely "the flesh and blood," concupiscence of the flesh and sensuality. It is clear for Aquinas that a man cannot win with such an intelligent enemy and another strategy has to be applied. It is trust in Christ who fights in my name (the strategy of war) and the adoption of the attitude of humility (the tactic of every battle).

Therefore it is very important that after the call: "Finally, brethren be strengthened in the Lord and in the power of his virtue" (De cetero, fratres, confortamini in Domino, et in potentia virtutis eius) Aquinas refers to the theme of trust (fiducia) because the full trust in God's assistance in Christ originates from absolute surrender to the power of grace and confidence. Aquinas says: "Now he speaks of the power by which we must carry out these precepts, for we must trust in divine assistance" (Hic ostendit qua virtute debent uti ad praecepta haec implenda, quia fiducia auxilii divini). It means that the believer who has left his own old world of sin and is invited to open for new life must leave everything behind and enter a new unknown sphere in the full trust in God in Christ and to adjust to the standard of new life. Unexpectedly, it is a spiritual struggle. It is necessary to make a move and begin carrying not your own grace but the grace of God in yourself having it readily available to apply. Leaving behind the old life and adopting the new style of life based on faithfulness and steadfastness of faith in divine assistance is not easy. It is necessary to put trust in God and to start a new life without looking backwards because it is possible to turn into a pillar of salt (like Lot's wife) out of pettiness before even starting the battle. ${ }^{11}$

11 Trust in Christ and giving Him priority in the fight against "Principalities and Powers" (the powers hostile to Christ and the people of God) are the basic elements of Christian fortitude. When St. Paul presents the spiritual struggle with enemies he says: "For we are not contending against flesh and blood, but against the principalities, against the powers, against the world rulers of this present darkness, against the spiritual hosts of wickedness in the heavenly places" (Eph 6:12). It is obvious that man cannot win with such an enemy. Connatural knowledge (iudicium per connaturalitatem), which signifies knowing God through the power of love as friendship (amor amicitiae) with Christ reveals the secrets and principles of acting in such a struggle. It has to be remembered that, spiritually, we are the members of the Body of Christ where Christ is the Head. Satan wants to separate the believers from the Head and when the believers fall, Satan wins the struggle. Human beings are not strong enough to win this fight; this can be achieved only in Christ (cf P. F. Beatrice, Il combattimento spirituale secondo San Paolo. Interpretazione di Ef 6:1-17, 359-422). Jesus Christ reminds his disciples: "Be shrewd as serpents" (Mt 10:16). Such an action means undertaking this call where in order to protect Christ in us we give everything to Him as Jesus is the only strong one able to protect us (Cf. C. Colpe, Zur Leib-Christi-Vorstellung im Epheserbrief, 173-187). 
In the Commentary (cap.6, lect.3, n. 351-358), the main emphasis is placed on the power hidden in trust. The word fiducia used in this context signals divini auxilium. The assistance of God who is unconditionally faithful, loyal, steadfast, devoted and reliable indicates His final victory. Fiducia (trust) and faithful assistance (auxilium) seem to be an echo of the call from the Old Testament: hesed we'emet (Hebrew) which always combines grace with faithfulness and the first word does not exist without an answer of the second one. In Thomas' case, fiducia-auxilium serves as a kind of hendiadys, namely, the expression of a single idea by two words. If it is still not clear for someone, Thomas gives a particular instruction and explains the reason for our trust saying; "it is not our battle" and "blessed is the one who trusts in the Lord, whose confidence is in him" (Jr 17:7). The battle is not ours but it concerns us.

It is clear that the mutual relation between trust and divine assistance has a character of a rule (praecepta). One may think that it is insulting for trust to be normalized by some rules. However, it must be remembered that this unity of notions trust-assistance is based not on my obligation but on God's obligation of being faithful in granting assistance. It is God that undertakes the obligation of helping me regardless of my condition. This is the obligation of assistance - the Covenant - which He made with His people. He remains faithful to this Covenant and it is the gift of the grace of trust and hope granted by God Himself. Human trust reveals here its true nature because people do not need to be afraid of undertaking obligations (fulfilling commandments) as from the very beginning this unconditional God's assistance, His powerful right hand, supports them in the battle with the biggest enemies (sin, death and Satan). God, the Father, revealed everything to people in the victorious battle with the powers of darkness when He rose his Son, Jesus Christ from the dead. His right hand is victorious and being the faithful assistance of man will appear as such in human fight. Human beings are strong not in themselves but in Him. God who granted His Son everything, assigned the work to Him because $\mathrm{He}$ emerged victorious from the battle.

Thus Thomas' practical advice gives impulse to put confidence in Christ and bow humbly before His power.

\section{By way of an ending}

The Commentary on the Epistle to the Ephesians by St. Thomas Aquinas is a teaching on the precepts of grace (praecepta gratiae), namely how to benefit from the power of Christ. 
The believer incorporated in the Mystical Body of Christ understands the requirements of Christ's teaching and what constitutes the imitation of the power of Christ: "you heard about Christ and were taught in him in accordance with the truth that is in Jesus" (Eph 4:21). By the power of the Holy Spirit it is clear that Christians who are made participants of the divine nature through the novelty of their lives are able to relate the work of their renewal. They tell others about the power they have experienced and it is their apostolic vocation.

Reading the whole Thomas' commentary it is possible to detect the transition from the Prologue to other chapters and lectures. Thus in the Prologue, as in a nutshell, the hidden theme, which Aquinas develops further according to the text of the Epistle, is included. Faith is not given for its own sake but should illuminate everything around. The fruit of the power of grace received from Christ is, among others, the light. Whereas the received "glory" is not vanity (inanis gloria) but outer proclamation of inner truth. According to Aquinas, there are two effects of predestination, grace and glory (cap. 1, lect. 1, n. 12) (effectus praedestinationis sunt duo, scilicet gratia et gloria). God gives His grace so that man could extol God's goodness. God created man "for His glory" (cf. Is 43:7) and man filled with the strength of grace reveals God's glory discovering what is invisible, namely goodness and love of God.

Man desires divine grace for himself as it transforms him not for his own sake but for God. What man possesses is due to the grace which God endowed him with. The glory of God reflected by the power of grace in the face of those who believe in Christ is for the good of others: "so that they may see your good works and give glory to your Father in heaven" (Mt 5:16). All these references quoted in this context are of paramount importance in understanding the role of the virtue of fortitude. Thus fortitude may be conceived as the particular virtue (virtus particularis), namely one of the cardinal virtues but also due to its universal reference to all the dispositions and virtues mentioned above it may be characterized as a general virtue (generalis) since it directs all the acts of the virtues to its own end. What does Aquinas mean by this?

It is difficult for an untutored reader to understand the full dynamics of the texts and notice references to the virtue of fortitude and it is so because the word virtus itself denotes fortitude so it is not necessary to add the noun fortitudinis. When Aquinas mentions some virtue, namely virtus he already implies its power/strength. Power/strength $=$ virtus of reason is the power of the virtue of prudence, the virtue of justice, in turn, is nothing else but the power of virtue of proper relations with God, other men and oneself (as we have seen previously), the virtue of temperance is the power of sobriety and discipline. "Fortitude would seem to derive its name from firmness. But it belongs to eve- 
ry virtue to stand firm." ${ }^{12}$ It is virtus that is the power which defends the honor of all virtues and guards their behest; it will not snuff out the "smoldering wick" of any impulse of goodness. Aquinas says that fortitude is a condition of every virtue (conditio cuiuslibet virtutis), as it is with the firmness of spirit (firmitas animi) in general. ${ }^{13}$

\section{References}

Abbott T.K., A Critical and Exegetical Commentary on the Epistles to the Ephesians and to the Colossians, The International Critical Commentary, Edinburgh 1897.

Ambrosiaster, Commentaria in duodecim Epistolas Beati Pauli, PL 17, 47-536; Super Epistolam ad Ephesios, PL 17, 393-426; CSEL LXXXI: Ambrosiastri qui dicitur Commentarius in Epistolas Paulinas, recensuit H. I Voges, Vindobonae 1969, III, 69-126.

Anselmus Cantuariensis, Divi Anselmi Cantuariensia Archiepiscopi in omnes sanctissimi Pauli Apostoli epistolas enarrationes, Coloniae MDXXXIII, 298-334.

Arystoteles, Etyka nikomachejska, (trans. D. Gromska) Państwowe Wydawnictwo PWN, Warszawa 2007.

Augustinus, Sermones ad Populum, serm. I-CCCXL, PL 38, 23-1484; serm. CCCXLICCCXCVI, PL 39, 1493-1718.

Bajda J, Rozmyślanie nad Listem do Efezjan, Ethos, 1998, n. 3 (11), 67-76.

Barth M., Ephesians, Anchor Bible 34-34A, Garden City NY 1974; R. Schnackenburg, Der Brief an die Epheser, Evangelisch-Katholischr Kommentar zum Neuen Testament X, Zürich-Neukirchen 1982.

Beatrice P.F., Il combattimento spirituale secondo San Paolo. Interpretazione di Ef 6,1-17, Studia Patavina, 1972, 19, 359-422.

Colpe C., Zur Leib-Christi-Vorstellung im Epheserbrief, in: Judentum, Urchristentum, Kirche. Festschrift J. Jeremias, Berlin 1960, 173-187.

Erasmus Roterodamus, Adnotationes in Novum Testamentum, Basileae 1519-Franfurt am Main 1695, V, 549-658.

Joannes Chrisostomus, In Epistolam ad Ephesios Commentarius, PG 62, 9-176; Oeuvres complètes de Saint Jean Chrysostome, par l'Abbé J. Bareille, Paris 1872, XVIII, 168-447.

Gnilka J., Der Epheserbrief, HerdersTheologischer Kommentar zum Neuen Testament, X/2, Freiburg-Basel-Wien 1971.

Horvat S., Neuroscientific findings in the light of Aquinas' understanding of the human being, Scientia et Fides, 2 (2017), 127-153

Jankowski A., List do Efezjan (Pismo Święte Starego i Nowego Testamentu. W przekładzie z języków oryginalnych), Pallottinum, Poznań-Warszawa 1984, 1439-1445.

Cf. S. Th., II-II, q. 123, a. 2 , ad 3.

13 Cf. S. Th., II-II, q. 123, a. 2c. 
Kinnear A., Życie w Chrystusie. List do Efezjan, (org. Sit walk stand. What shall this man do?), (trans. J. Prower), Warszawa 1964.

Langkammer H., List do Efezjan, in: Wstęp do Nowego Testamentu, ed. R. Rubinkiewicz, Pallottinum, Poznań 1960, 374-381.

Langkammer H., Problemy literackie Listu do Efezjan, jego aspekty teologiczne i jego eklezjologia, Roczniki Teologii Katolickiej, 1980, n. 1 (127), 93-102.

Mędala S., Tajemnica Bożej ekonomii. List do Efezjan, in: J. Frankowski, S. Mędala, Dzieje Apostolskie. Listy św. Pawła, ATK, Warszawa 1997, vol. 9, 448-485.

Mróz M., Virtue epistemology and Aquinas's Biblical Commentary to the Corpus Paulinum, in: P. Roszak, J. Vijgen, Reading Sacred Scripture with Thomas Aquinas. Hermeneutical Tools, Theological Questions and New Perspectives, Brepols 2015, 435-456.

Murray P. OP, Aquinas at Prayer. The Bible, Mysticism and Poetry, Bloomsbury Publishing, London-New Delhi-New York-Sydney 2013.

Penna R., Lettera agli Efesini. Introduzione, versione, commento, Edizioni Dehoniane Bologna 1988.

Pieper J., Vom Sinn der Tapferkeit, Hegner, Leipzig 1934.

Pytel J., List do Efezjan, in: Zanim otworzysz Biblie, ed. M. Peter, (Stary Testament), M. Wolniewicz, (Nowy Testament), Księgarnia św. Wojciecha, Poznań 1981, 169-170.

Sikora R., Kościół jako ciało Chrystusa w Kol i Ef, Roczniki Teologii Katolickiej, 1997, n. 1 (44), 29-138.

Staniek E., Bogactwo natchnionych ksiąg. List do Efezjan. Jedność w Chrystusie, Materiały Homiletyczne, 1981, n. 123, 30-36.

Staniek E., Żyjemy w świecie pogan, Petrus, Kraków 2013.

Suski A., Il salmo di lode nella lettera agli Efesisni. Tentativo do ricostruzione ed aspetti teologici, Roma, Dissertatione, Roma 1973.

S. Thomae Aquinatis, Super Epistolas S. Pauli lectura, t. 2: Super Epistolam ad Ephesios lectura, ed. R. CAI (8 ed.), Marietti, Taurini-Romae 1953, 1-87.

Tomasz z Akwinu, Wykład Listu do Efezjan (Super Epistolam B. Pauli ad Ephesios lectura), ed. P. Roszak, E. Alarcón, Wydawnictwo Naukowe Uniwersytetu Mikołaja Kopernika, Toruń 2017.

St. Thomas Aquinas, Commentary on Saint Paul's. Epistle to the Ephesians, translation and introduction by Matthew L. Lamb, Magi Books Albany (N.Y.) 1966.

Torrrell J.-P., Święty Tomasz z Akwinu - mistrz duchowy, trans. A. Kuryś, W drodze, Poznań 2003.

Vijgen J., Soul or Brain: A False Dilemma? The Thomist Perspective, Scientia et Fides, 2 (2017), 71-86. DOI: http://dx.doi.org/10.12775/SetF.2017.015. 